\title{
Immunoexpression of lactoferrin in human sporadic renal cell carcinomas
}

\author{
GIUSEPPE GIUFFRÈ, VALERIA BARRESI, CHRISTODOULOS SKLIROS, \\ GAETANO BARRESI and GIOVANNI TUCCARI
}

\begin{abstract}
Department of Human Pathology, University of Messina, Azienda Ospedaliera Universitaria
'Policlinico G. Martino', Via Consolare Valeria, I-98125 Messina, Italy
\end{abstract}

Received August 16, 2006; Accepted September 29, 2006

\begin{abstract}
By immunohistochemistry, lactoferrin (Lf) expression was retrospectively investigated in 40 formalinfixed paraffin-embedded kidney samples, obtained at surgery from an equal number of patients. Histologically, 28 cases were clear cell carcinomas (CCC), 7 papillary carcinomas (PC) and 5 chromophobe carcinomas (CC). Ten specimens of unaffected renal parenchyma were utilized as tissue control. On $4-\mu \mathrm{m}$ thick sections, the Lf immunoreactivity was revealed either by a rabbit polyclonal or mouse monoclonal anti-human Lf antisera; the quantification of Lf immunoreactivity was performed using an intensity-distribution (ID) score. A positive immunoreaction by both anti-Lf antibodies was found in $62.5 \%(25 / 40)$ of RCC, mainly evident and diffuse by monoclonal antiserum. The immunoreactivity was observed in the cytoplasmic boundary of neoplastic cells in CCC and PC, while in CC Lf showed a diffuse granular cytoplasmic localization. Moreover, significant differences in Lf ID score were found among CCC and non-CCC variants $(\mathrm{P}<0.00001)$, the former showed a lower score; no relationships between immunohistochemical data and the sex or age of patients, grade of RCC, stage of the disease or degree of terminal anemia were encountered. Normal unaffected tubular structures were positive for Lf; glomeruli were unstained. The reduced $\mathrm{Lf}$ immunoexpression in some CCC may be because of the down-regulation of $\mathrm{Lf}$ gene due to the frequent deletion of $3 p$ regions reported in this RCC variant.
\end{abstract}

\section{Introduction}

Lactoferrin (Lf), an $80-\mathrm{kDa}$ basic glycoprotein, is a member of the transferrin family of iron-binding protein, which was originally isolated from human milk (1). By radioimmuno-

Correspondence to: Professor Giovanni Tuccari, Department of Human Pathology, Azienda Ospedaliera Universitaria, 'Policlinico G. Martino', pad. D, Via Consolare Valeria, I-98125 Messina, Italy E-mail: tuccari@unime.it

Key words: renal carcinoma, lactoferrin, immunohistochemistry, $3 \mathrm{p}$ region logical and immunoenzymatic procedures, Lf has been detected in many biological fluids as well as in human fetal and adult tissues (2-7). By immunohistochemistry, the distribution of Lf has been analysed in normal human tissues such as stomach, kidney, lung, pancreas, liver and bone marrow (4). In human neoplastic conditions, the Lf immunoreactivity has been extensively investigated (8-20); in particular, a variable immunohistochemical pattern of this iron-binding protein has been reported in adenocarcinomas of the parotid gland (8), prostatic carcinomas (9), breast carcinomas $(10,11)$, thyroid tumours $(12,13,16,18)$, gastric adenomas and carcinomas (15), colorectal adenomas and carcinomas (17), gallbladder carcinomas (19), astrocytomas and multiforme glioblastomas (20), pigmented skin lesions (21) and endometrial carcinomas (22).

Under normal conditions, the tubular epithelium of the human kidney is stained for Lf, while glomeruli are nonreactive (4). In a small series (14), Lf has been detected by peroxidase and immunofluorescence in some cases of renal cell carcinomas and its presence has been related to the degree of anemia present in late phases of this neoplastic condition.

In the present study, by monoclonal and polyclonal antibodies, we have investigated the immunohistochemical distribution pattern of $\mathrm{Lf}$ in a retrospective series of sporadic renal cell carcinomas, in order to verify if differences in Lf immunoreactivity related to different antisera as well as relationships between Lf immunoexpression and clinicopathological parameters.

\section{Materials and methods}

We investigated $\mathrm{Lf}$ immunoexpression in 40 sporadic renal cell carcinoma (RCC) samples (23 left and 17 right kidneys), taken from files of our Department, previously obtained at surgery from an equal number of patients ( 24 male, 16 female; age range 33-80 years, mean 62). Histologically, 28 cases were clear cell carcinomas (CCC), 7 papillary carcinomas (PC) and 5 chromophobe carcinomas (CC); moreover a sarcomatoid differentiation was encountered in two and one case of CCC and PC, respectively. The grading and staging of RCCs were performed by a 4-tiered system and TNM classification, respectively (23) (Table I). In addition, 10 specimens of unaffected renal parenchyma obtained at surgery or at autopsy were utilized as tissue control. 
Table I. Immunohistochemical detection of Lf in renal cell carcinoma specimens.

\begin{tabular}{|c|c|c|c|c|c|c|c|c|c|}
\hline Case & Sex & Age & Kidney & Histotype & Grade & TNM stage & $\begin{array}{l}\text { Lf staining } \\
\text { distribution }\end{array}$ & $\begin{array}{l}\text { Lf staining } \\
\text { intensity }\end{array}$ & $\begin{array}{l}\text { Lf ID } \\
\text { score }\end{array}$ \\
\hline 1 & $\mathrm{~F}$ & 73 & $\mathrm{Sn}$ & $\mathrm{CCC}$ & 1 & I & 0 & 0 & 0 \\
\hline 2 & $\mathbf{M}$ & 80 & Dx & $\mathrm{CCC}$ & 3 & I & 0 & 0 & 0 \\
\hline 3 & $\mathbf{M}$ & 68 & $\mathrm{Sn}$ & $\mathrm{CCC}$ & 4 & III & 0 & 0 & 0 \\
\hline 4 & $\mathrm{~F}$ & 61 & $\mathrm{Dx}$ & $\mathrm{CCC}$ & 2 & III & 0 & 0 & 0 \\
\hline 5 & $\mathrm{~F}$ & 58 & Sn & $\mathrm{CCC}$ & 3 & I & 0 & 0 & 0 \\
\hline 6 & $\mathrm{~F}$ & 64 & Dx & $\mathrm{CCC}$ & 3 & I & 0 & 0 & 0 \\
\hline 7 & M & 44 & Sn & $\mathrm{CCC}$ & 2 & IV & 0 & 0 & 0 \\
\hline 8 & $\mathrm{~F}$ & 62 & Sn & $\mathrm{CCC}$ & 2 & III & 0 & 0 & 0 \\
\hline 9 & M & 69 & $\mathrm{Sn}$ & $\mathrm{CCC}$ & 4 & II & 0 & 0 & 0 \\
\hline 10 & M & 67 & $\mathrm{Sn}$ & $\mathrm{CCC}$ & 2 & I & 0 & 0 & 0 \\
\hline 11 & $\mathrm{~F}$ & 59 & $\mathrm{Sn}$ & $\mathrm{CCC}$ & 2 & III & 0 & 0 & 0 \\
\hline 12 & M & 45 & $\mathrm{Sn}$ & $\mathrm{CCC}$ & 1 & I & 0 & 0 & 0 \\
\hline 13 & $\mathbf{M}$ & 65 & Dx & $\mathrm{CCC}$ & 2 & II & 0 & 0 & 0 \\
\hline 14 & $\mathrm{~F}$ & 58 & Sn & $\mathrm{CCC}$ & 2 & III & 0 & 0 & 0 \\
\hline 15 & M & 72 & $\mathrm{Sn}$ & $\mathrm{CCC}$ & 2 & I & 0 & 0 & 0 \\
\hline 16 & $\mathbf{M}$ & 74 & $\mathrm{Sn}$ & $\mathrm{CCC}$ & 3 & II & 1 & 1 & 1 \\
\hline 17 & $\mathrm{~F}$ & 60 & Sn & $\mathrm{CCC}$ & 3 & III & 1 & 1 & 1 \\
\hline 18 & $\mathbf{M}$ & 52 & Dx & $\mathrm{CCC}$ & 1 & I & 1 & 1 & 1 \\
\hline 19 & $\mathrm{~F}$ & 62 & Dx & $\mathrm{CCC}$ & 1 & I & 1 & 1 & 1 \\
\hline 20 & $\mathbf{M}$ & 60 & $\mathrm{Sn}$ & $\mathrm{CCC}$ & 3 & III & 1 & 1 & 1 \\
\hline 21 & $\mathrm{~F}$ & 63 & Dx & $\mathrm{CCC}$ & 2 & I & 1 & 1 & 1 \\
\hline 22 & $\mathbf{M}$ & 71 & $\mathrm{Sn}$ & $\mathrm{CCC}$ & 2 & II & 1 & 1 & 1 \\
\hline 23 & M & 70 & $\mathrm{Sn}$ & $\mathrm{CCC}$ & 3 & III & 1 & 1 & 1 \\
\hline 24 & $\mathrm{M}$ & 72 & Sn & $\mathrm{CCC}$ & 2 & III & 1 & 1 & 1 \\
\hline 25 & $F$ & 58 & $\mathrm{Dx}$ & $\mathrm{CCC}$ & 3 & I & 1 & 1 & 1 \\
\hline 26 & $\mathbf{M}$ & 73 & Sn & $\mathrm{CCC}$ & 1 & III & 1 & 1 & 1 \\
\hline 27 & $\mathrm{~F}$ & 41 & $\mathrm{Dx}$ & $\mathrm{CCC}$ & 2 & I & 1 & 2 & 2 \\
\hline 28 & $\mathbf{M}$ & 75 & $\mathrm{Sn}$ & $\mathrm{CCC}^{\mathrm{a}}$ & 3 & IV & 1 & 1 & 1 \\
\hline 29 & $\mathbf{M}$ & 51 & $\mathrm{Dx}$ & $\mathrm{PC}$ & 2 & II & 2 & 1 & 2 \\
\hline 30 & $\mathbf{M}$ & 60 & Sn & PC & 1 & I & 2 & 1 & 2 \\
\hline 31 & $\mathbf{M}$ & 52 & $\mathrm{Dx}$ & $\mathrm{PC}$ & 1 & II & 2 & 1 & 2 \\
\hline 32 & M & 55 & Sn & $\mathrm{PC}$ & 2 & I & 2 & 1 & 2 \\
\hline 33 & $\mathbf{M}$ & 66 & $\mathrm{Dx}$ & PC & 4 & I & 2 & 1 & 2 \\
\hline 34 & $\mathrm{~F}$ & 56 & $\mathrm{Sn}$ & $\mathrm{PC}^{\mathrm{a}}$ & 4 & I & 2 & 2 & 4 \\
\hline 35 & $\mathrm{~F}$ & 78 & $\mathrm{Dx}$ & $\mathrm{PC}^{\mathrm{a}}$ & 3 & III & 2 & 2 & 4 \\
\hline 36 & $\mathrm{~F}$ & 33 & Sn & $\mathrm{CC}$ & 1 & I & 1 & 2 & 2 \\
\hline 37 & $\mathrm{M}$ & 61 & Dx & $\mathrm{CC}$ & 3 & I & 2 & 1 & 2 \\
\hline 38 & $\mathbf{M}$ & 60 & Dx & $\mathrm{CC}$ & 2 & I & 2 & 1 & 2 \\
\hline 39 & $\mathrm{M}$ & 86 & Dx & $\mathrm{CC}$ & 2 & II & 2 & 2 & 4 \\
\hline 40 & $F$ & 35 & Dx & $\mathrm{CC}$ & 3 & II & 2 & 2 & 4 \\
\hline
\end{tabular}

${ }^{\mathrm{a} C}$ ases with sarcomatoid differentiation. CCC, clear cell carcinoma; PC, papillary carcinoma; CC, chromophobe carcinoma.

All samples were fixed in $10 \%$ neutral formalin for $24 \mathrm{~h}$ at room temperature (RT) and then embedded in paraffin at $56^{\circ} \mathrm{C}$. From each tissue block, three serial $4-\mu \mathrm{m}$-thick sections were cut and mounted on silane-coated glasses, then dewaxed in xylene and rehydrated in graded ethanols. One section was subjected to haematoxylin and eosin (H\&E) stain, the others were utilized for the immunohistochemical analysis. Antigen retrieval, by heating slides placed in $0.01 \mathrm{M}$ citrate buffer pH 6.0 in a microwave oven for 3 cycles x $5 \mathrm{~min}$, was performed before adding primary antibodies. For the immuno- 
histochemical study, sections were treated in a moist chamber: i) with $0.1 \% \mathrm{H}_{2} \mathrm{O}_{2}$ in methanol to block the intrinsic peroxidase activity ( $30 \mathrm{~min}$ at $\mathrm{RT}$ ); ii) with normal sheep serum to prevent unspecific adherence of serum proteins; iii) with polyclonal (rabbit anti-human lactoferrin, DakoCytomation, Denmark 1:300; overnight at $4^{\circ} \mathrm{C}$ ) as well as monoclonal (Clone 1A1; Biodesign International, USA; w.d. 1:75; 60 min at RT) primary antibodies anti-human Lf; iv) with sheep antirabbit or anti-mouse immunoglobulin antiserum (Behring Institute; w.d. 1:25; 30 min at RT); and v) with rabbit or mouse anti-horseradish peroxidase-antiperoxidase complexes (DakoCytomation; w.d. 1:25; 30 min at RT). For the demonstration of peroxidase activity the sections were incubated in darkness (24) for 10 min with 3-3' diaminobenzidine tetrahydrochloride (Sigma Chemical Co., St. Louis, MO, USA), in the amount of $100 \mathrm{mg}$ in $200 \mathrm{ml} 0.03 \%$ hydrogen peroxide in phosphate-buffered saline (PBS). The nuclear counterstaining was performed by Mayer's haemalum.

To test the specificity of Lf immunostaining in order to deny the possibility of non-specific reaction, serial sections of each affected renal specimen were tested by replacing the specific antiserum by either PBS, normal rabbit serum or absorbing with excess of purified human $\mathrm{Lf}$ from human liver and spleen (Sigma Chemical Co.) as well as with pre-absorbed primary antibody: the results obtained were negative. Moreover, the Lf immunoreactivity demonstrated in granules of polymorphonuclear neutrophils present inside lesions was utilized as positive control. Finally, in order to test the interrun variability of Lf staining, the same Lf-positive parotid sample was utilized in every run.

Immunostained sections were estimated by light microscopy using a x20 and $\times 40$ objective lens and $x 10$ eyepiece. Two pathologists using a double-headed microscope performed the assessment of Lf immunostained sections on a consensus basis. The percentage of stained neoplastic epithelial cells (staining distribution) was graded as follows: 0 (no staining); 1 (>0-5\%); 2 (>5-50\%); and $3(>50 \%)$. In addition, the staining intensity (weak, 1; moderate, 2; strong, 3) was also taken into consideration. Successively, Lf intensity-distribution (ID) score was calculated by multiplying, for each case, the staining intensity by the staining distribution, similarly to that reported $(25,26)$.

The possible correlations between immunohistochemical data, reported as Lf ID-score, and clinicopathological data of renal specimens were investigated using non-parametric methods (Mann-Whitney U test; Kruskal-Wallis $\mathrm{H}$ test). A probability $(\mathrm{P})$ value $<0.05$ was considered statistically significant. Data were analysed using the SPSS package version 6.1.3 (SPSS Inc., Chicago, IL).

\section{Results}

A positive immunoreaction with monoclonal as well as polyclonal anti-Lf antibodies was found in 62.5\% (25/40) of RCC. The immunoreactivity was mainly observed in the cytoplasm of neoplastic renal cells, although an occasional nuclear immunolocalization was encountered. The Lf immunostaining was mainly evident and diffuse utilizing the monoclonal antibody (Fig. 1a), while the polyclonal one showed a more focal and slight positivity in neoplastic elements present in
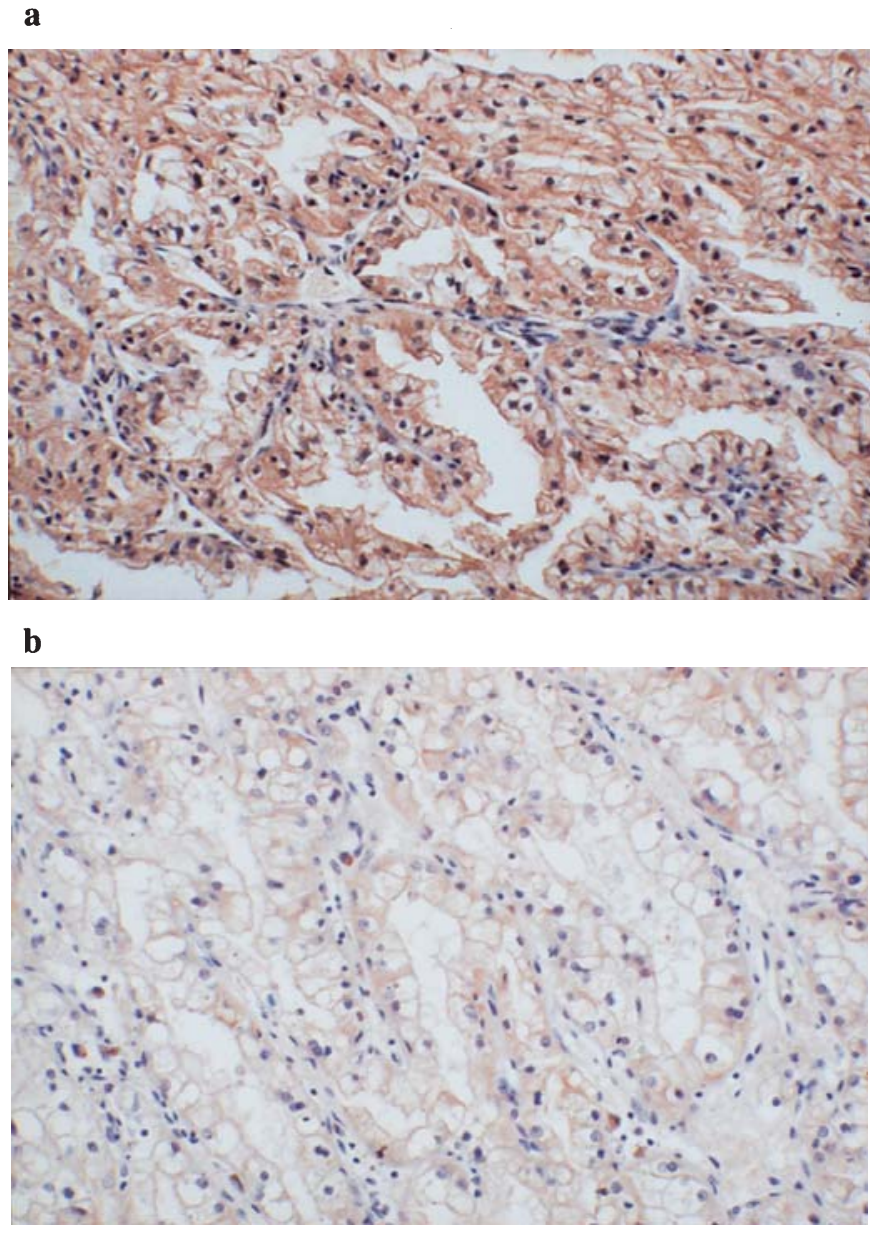

Figure 1. Lf immunoreactivity: (a), evident cytoplasmic positivity was found at the periphery of neoplastic elements in clear cell variant by Lf monoclonal antiserum; (b), slight staining was appreciable in the same elements by $\mathrm{Lf}$ polyclonal antiserum (immunoperoxidase, Mayer's haemalum counterstain).

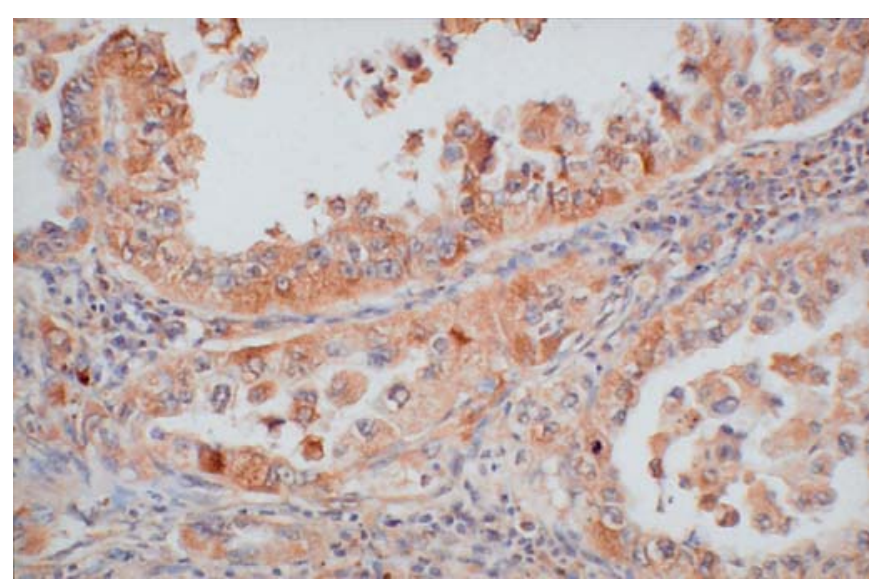

Figure 2. In papillary variant of RCC, neoplastic elements were intensely stained for Lf (immunoperoxidase, Mayer's, haemalum counterstain).

corresponding serial sections (Fig. 1b). The pattern of positivity was different in RCC variants. In CCC (Fig. 1a), PC (Fig. 2) as well as in sarcomatoid component (Fig. 3) Lf immunostaining was mainly evident at the cytoplasmic 


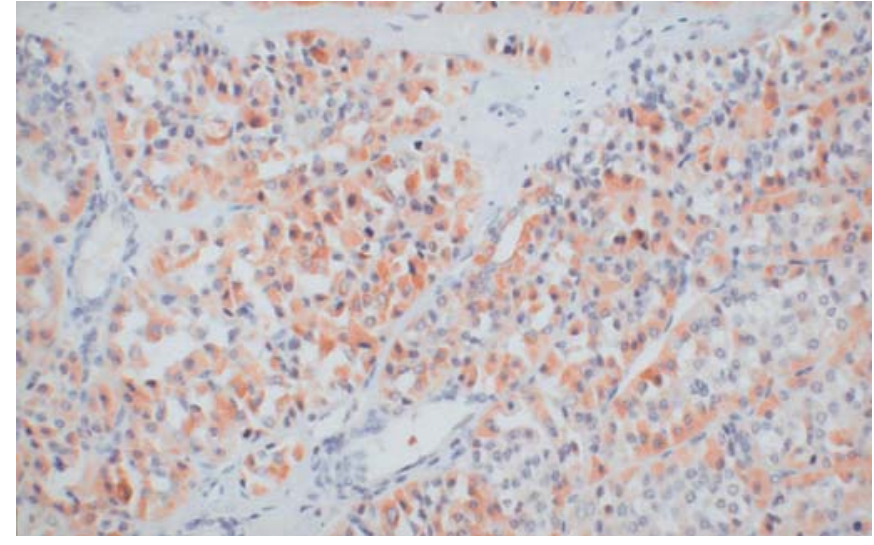

Figure 3. Cromophobe Lf positively-stained cells were found in direct contact with negative ones (immunoperoxidase, Mayer's haemalum counterstain).

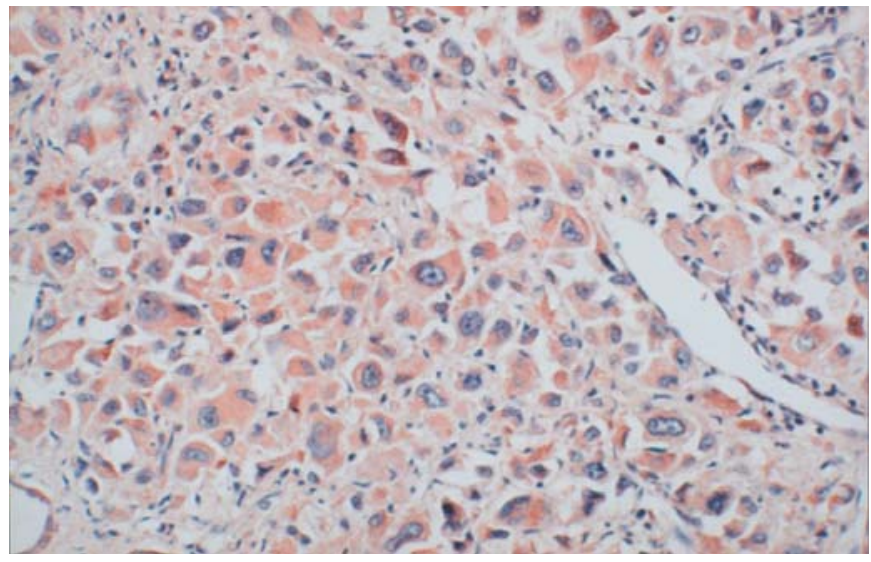

Figure 4. The Lf immunoreactivity was diffusely revealed in sarcomatoid atypical cells by monoclonal antiserum (immunoperoxidase, Mayer's haemalum counterstain).

boundary of neoplastic cells. In CC variant, Lf showed a diffuse granular cytoplasmic immunolocalization, with intensely stained positive cromophobe elements in direct contact with negative ones (Fig. 4).

Immunohistochemical data obtained by Lf monoclonal antibody and related to clinicopathological characteristics of $\mathrm{RCC}$ are given in Table I. Lf immunoexpression was different in histological variants of RCC; 13/28 (46.4\%) cases of CCC showed immunoreactivity with an ID score ranging from 0 to 2 (median value 0 ), while all cases of $\mathrm{PC}$ and $\mathrm{CC}$ were positive with an ID score ranging from 2 to 4 (median value 2). When all examined RCC were analyzed by MannWhitney $U$ test, significant differences in Lf ID score were found among CCC (mean rank 14.64) and non-CCC (mean rank 34.17) variants $(\mathrm{P}<0.00001)$; moreover, no relationships between immunohistochemical data and the sex or age of patients, grade of RCC, stage of the disease as well as degree of terminal anemia were encountered.

Normal unaffected tubular structures (Fig. 5), as well as polymorphonuclear neutrophils or monocytes were positive for Lf; by contrast, glomeruli were unstained (Fig. 5).

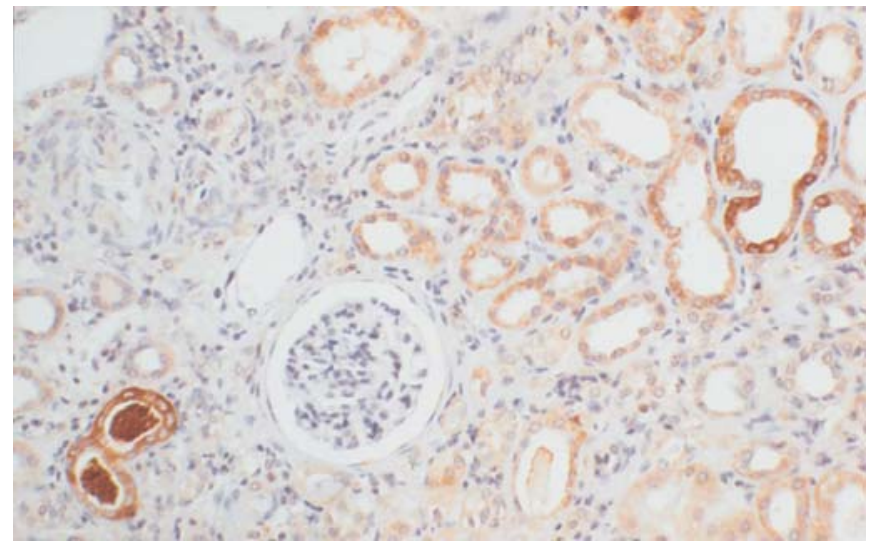

Figure 5. Tubular structures were reactive with Lf antisera, while glomeruli were unstained (immunoperoxidase, Mayer's haemalum counterstain).

\section{Discussion}

In the present study we report Lf immunostaining in RCC utilizing different antibodies, either polyclonal or monoclonal, Lf was detected in the cytoplasm of $25 / 40$ RCC (62.5\%) with a variable ID score, although an occasional nuclear immunolocalization was also found. The site of Lf immunoreactivity both in the nucleus and cytoplasm is not surprising, since this secretory protein has been already detected in the nucleus, mainly in nucleoli, and it has been thought to be involved in ribosomal biogenesis $(27,28)$. On the other hand, after its transport into the nucleus, Lf is able to bind to specific DNA sequences, activating transcription (28). Furthermore, the pattern of Lf positivity was different in clear cell, papillary or cromophobe RCC variants; neoplastic clear cells exhibited a Lf immunolocalization mainly evident at the cytoplasmic boundary, while immunoreactive cromophobe elements were found in direct contact with negative ones showing a diffuse granular Lf cyto-plasmic distribution. Although the Lf immunostaining in RCC was appreciable with both antisera, the highest ID score was achieved by the monoclonal one; therefore, the present approach to $\mathrm{Lf}$ distribution seems to indicate the monoclonal antibody is more specific and sensitive, able to bind all reactive epitopes either masked or unmasked. However, the exposure and/or conformation of the epitopes for the monoclonal antibodies appeared not to be affected by the conformational changes subject to incorporation of iron in Lf, allowing thus a greater affinity between antigenic determinants and monoclonal antibodies (29).

Many biological functions of $\mathrm{Lf}$ have been addressed including regulation of iron homeostasis, antioxidant and immunoregulatory activities, bacteriostatic and bactericidal effects as well as the capability to curb the proliferation of other microbes such as fungi and viruses (30-37). In our study, Lf immunoexpression was found in areas of renal parenchyma adjacent to neoplasms, mainly in the proximal tubular structures, while glomeruli were unstained. It could be argued that the presence of Lf in tubular non-neoplastic cells may be related to its endogenous production in order to activate the host defence system by Lf specific functions, 
such as antioxidant role, interleukin activation and $\mathrm{T}$ lymphocyte proliferation. Interestingly, although the histogenesis of RCC has been widely attributed to tubular cells (23), a quote of our cohort of CCC variant was unstained for Lf. However, this iron-binding multi-function protein is coded by a gene present in the short arm of chromosome $3(3 \mathrm{p})$ $(38-40)$ and $3 p$-regions may be deleted in some $\operatorname{RCC}(23,41)$. Therefore, the evidence of a reduced $\mathrm{Lf}$ immunoexpression in CCC should refer to the down-regulation of Lf gene due to the frequent deletion of $3 p$ regions in this $R C C$ variant. Consequently, from a practical point of view, the immunohistochemical analysis of Lf distribution could help to identify renal tumours with a loss of this chromosomal region. Conversely, the presence of Lf in renal neoplastic elements might be related to the production of this iron-binding protein in the tumour itself as suggested by Lf immunostaining, although this interpretation should be controlled by methods other than morphological analysis. Alternatively, the cytoplasmic immunolocalization of Lf in neoplastic cells could not reflect an intracellular synthesis, being instead the consequence of defective or functionally impaired Lf receptors; specific Lf-binding sites have been shown in a human neoplastic cell line (42) and a receptor-mediated endocytosis could be hypothesized, similarly to that demonstrated for transferrin in growing cells (43); in this manner, the intracellular presence of Lf immunoreactivity may reveal the degree of transmembranous iron transfer.

It has been suggested that $\mathrm{Lf}$ inhibits cell proliferation and suppresses tumour growth in vivo (44-46), although the molecular mechanisms underlying these effects remain unknown. Nevertheless, it has been reported that treatment of breast carcinoma cells MDA-MB-231 with human Lf induces growth arrest at the $\mathrm{G} 1$ to $\mathrm{S}$ transition of the cell cycle (45); in addition, in adult rats, it has been shown that Lf treatment significantly inhibited the $\operatorname{VEGF}(165)$-mediated response in terms of microvessel spatial extension, overall vascularity and incidence of crossover (46). Finally, these effects of Lf on target cells appear to depend on the cell phenotype; in fact, Lf does not modify the susceptibility to lysis of haematopoietic cells such as Jurkat and K-562 cells, but does significantly increase that of the breast and colon epithelial cells (44). On the other hand, it is well known that Lf has a high affinity for iron, which has been considered an essential nutrient for cells that are dividing rapidly such as tumour cells, taking part in various metabolic cellular processes such as oxydative phosphorylation and RNA and DNA synthesis $(47,48)$; therefore, neoplastic renal cells should be able to utilize Lf in order to have a greater availability of iron for their turnover, similarly to that suggested in other neoplasms $(12,19,20)$. However, Lf has been shown to mediate the hyposideremia of acute inflammation (49) and a role for $\mathrm{Lf}$ as a mediator of the anemia associated with renal adenocarcinoma has been hypothesized since 10/24 RCC with low iron levels were positive with both FITC and peroxidase-conjugated antilactoferrin (14). We were unable to confirm the suggested relationship between anemia encountered in different neoplasms and a corresponding Lf immunoexpression $(15,17)$; moreover, in the present study, Lf immunostaining was not found in relation to the grade of RCC, site and stage of the disease neither with the degree of terminal anemia.

\section{Acknowledgements}

A section of this work has been selected for a poster presentation at the 11th World Congress on Advances in Oncology and 9th International Symposium on Molecular Medicine, 12-14 October, 2006, Hersonissos, Crete, Greece.

\section{References}

1. Steijns JM and van Hooijdonk ACM: Occurrence, structure, biochemical properties and technological characteristics of lactoferrin. Br J Nutr 84: 11-17, 2000.

2. Masson PL, Heremans JF and Dire $\mathrm{CH}$ : An iron-binding protein common to many external secretions. Clin Chim Acta 14: 735-739, 1966.

3. De Vet BJCM and van Gool J: Lactoferrin and iron absorption in the small intestine. Acta Med Scand 196: 393-402, 1974.

4. Mason DY and Taylor CR: Distribution of transferrin, ferritin and lactoferrin human tissues. J Clin Pathol 31: 316-327, 1978.

5. Brock J: Lactoferrin in human milk: its role in iron absorption and protection against enteric infection in the newborn infant. Arch Dis Child 55: 417-421, 1980.

6. Reitamo S, Kontinnen YT and Segerber-Kontinnen M: Distribution of lactoferrin in human salivary glands. Histochemistry 66: 285-291, 1980.

7. Korsrud FR and Brandtzaeg P: Characterization of epithelial elements in human major salivary glands by functional markers: localization of amylase, lactoferrin, lysozyme, secretory component, and secretory immunoglobulins by paired immunofluorescence staining. J Histochem Cytochem 30: 657-666, 1982.

8. Caselitz J, Jaup T and Seifert G: Lactoferrin and lysozyme in carcinomas of the parotid gland. Virchows Arch (A) 394: 61-73, 1981.

9. Barresi G and Tuccari G: Lactoferrin in benign hypertrophy and carcinomas of the prostatic gland. Virchows Arch (A) 403: 59-66, 1984.

10. Rossiello R, Carriero MV and Giordano GG: Distribution of ferritin, transferrin and lactoferrin in breast carcinoma tissue. $J$ Clin Pathol 37: 51-55, 1984.

11. Charpin C, Lachard A, Pourreau-Schneider N, et al: Localization of lactoferrin and non-specific cross-reacting antigen in human breast carcinomas. Cancer 55: 2612-2617, 1985.

12. Tuccari $G$ and Barresi $G$ : Immunohistochemical demonstration of lactoferrin in follicular adenomas and thyroid carcinomas. Virchows Arch (A) 406: 67-74, 1985.

13. Barresi $G$ and Tuccari $G$ : Iron-binding proteins in thyroid tumours. An immunocytochemical study. Path Res Pract 182: 344-351, 1987.

14. Loughlin KR, Gittes RF and Partridge D: The relationship of lactoferrin to the anemia of renal carcinoma. Cancer 59: 566-571, 1987.

15. Tuccari G, Barresi G, Arena F and Inferrera C: Immunocytochemical detection of lactoferrin in human gastric carcinomas and adenomas. Arch Pathol Lab Med 113: 912-916, 1989.

16. Cabaret V, Vilain MO, Delobelle-Deroide A and Vanseymortier L: Détection immunohistochimique de la céruloplasmine et de la lactoferrine sur une sèrie de 59 tumeurs thyroidiennes. Ann Pathol 12: 347-352, 1992.

17. Tuccari G, Rizzo A, Crisafulli $C$ and Barresi G: Iron-binding proteins in human colorectal adenomas and carcinomas: an immunocytochemical investigation. Histol Histopathol 7: 543-547, 1992.

18. Asato de Camargo RY, Longatto Filho A, Ferreira Alves VA, Bisi H, Takami Kanamura $C$ and Alves Abelin NM: Lactoferrin in thyroid lesions. Immunoreactivity in fine needle aspiration biopsy samples. Acta Cytol 40: 408-413, 1996.

19. Tuccari G, Rossiello $R$ and Barresi G: Iron binding proteins in gallbladder carcinomas. An immunocytochemical investigation. Histol Histopathol 12: 671-676, 1997.

20. Tuccari G, Giuffrè G, Crisafulli $C$ and Barresi G: Immunohistochemical detection of lactoferrin in human astrocytomas and multiforme glioblastomas. Eur J Histochem 43: 317-322, 1999.

21. Tuccari G, Giuffrè G, Scarfì R, Simone $A$, Todaro $P$ and Barresi G: Immunolocalization of lactoferrin in surgically resected pigmented skin lesions. Eur J Histochem 49: 33-38, 2005. 
22. Giuffrè G, Arena F, Scarfi R, Simone A, Todaro P and Tuccari G: Lactoferrin immunoexpression in endometrial carcinomas: relationships with sex steroid hormones receptors (ER and PR), proliferation indices (Ki-67 and AgNOR) and survival. Oncol Rep 16: 257-263, 2006.

23. Eble JN, Sauter G, Epstein JI and Sesterhenn IA (eds): Pathology and genetics of tumours of the urinary system and male genital organs. In: World Health Organization Classification of Tumours. IARC Press, Lyon, 2004.

24. Weir EE, Pretlow TG and Pitts A: A more sensitive and specific histochemical peroxidase stain for the localization of cellular antigen by the enzyme-antibody conjugate method. J Histochem Cytochem 22: 1135-1140, 1974.

25. Douglas-Jones AG, Schmid KW, Bier B, et al: Metallothionein expression in duct carcinoma in situ of the breast. Hum Pathol 26: 217-222, 1995.

26. Tuccari $G$, Giuffrè $G$, Arena $F$ and Barresi G: Immunohistochemical detection of metallothionein in carcinomatous and normal human gastric mucosa. Histol Histopathol 15: 1035-1041, 2000.

27. Garrè C, Bianchi-Scarra G, Sirito M, Musso M and Ravazzolo R: Lactoferrin binding sites and nuclear localization in K562(S) cells. J Cell Physiol 153: 477-482, 1992.

28. Penco S, Scarfi S, Giovine M, et al: Identification of an import signal for, and the nuclear localization of, human lactoferrin. Biotechnol Appl Biochem 34: 151-159, 2001.

29. Van Berkel PHC, van Veen HA, Geerts MEJ and Nuijens JH: Characterization of monoclonal antibodies against human lactoferrin. J Immunol Methods 267: 139-150, 2002.

30. Brock J: Lactoferrin: a multifunctional immunoregolatory protein? Immunol Today 16: 417-419, 1995.

31. Defer MC, Dugas B, Picard O and Damais C: Impairment of circulating lactoferrin in HIV-1 infection. Cell Mol Biol 41: 417-421, 1995.

32. Fujihara $\mathrm{T}$ and Hayashi $\mathrm{K}$ : Lactoferrin inhibits herpes simplex virus type-1 (HSV-1) infection to mouse cornea. Arch Virol 140: 1469-1472, 1995.

33. Levay PF and Viljoen M: Lactoferrin: a general review. Haematologica 80: 252-267, 1995.

34. Lonnerdal B and Lyer S: Lactoferrin: molecular structure and biological function. Annu Rev Nutr 15: 93-110, 1995.

35. Ikeda M, Sugiyama K, Tanaka $\mathrm{T}$, et al: Lactoferrin markedly inhibits hepatitis $C$ virus infection in cultured human hepatocytes. Biochem Biophys Res Commun 245: 549-553, 1998.

36. Tanaka $K$, Ikeda $M$, Nozaki A, et al: Lactoferrin inhibits hepatitis $\mathrm{C}$ virus viremia in patients with chronic hepatitis $\mathrm{C}$ : a pilot study. Jpn J Cancer Res 90: 367-371, 1999.
37. Tuccari G, Villari D, Giuffrè G, et al: Immunohistochemical evidence of lactoferrin in hepatic biopsies of patients with viral or cryptogenetic chronic liver disease. Histol Histopathol 17: $1077-1083,2002$

38. McCombs JL, Teng CT, Pentecost BT, et al: Chromosomal localization of human lactotransferrin gene (LTF) by in situ hybridization. Cytogenet Cell Genet 47: 16-17, 1988.

39. Yang Y, Li J, Szeles A, Imreh MP, Kost-Alimova M, Kiss H, Kholodnyuk I, Fedorova L, Darai E, Klein G and Imreh S: Consistent down-regulation of human lactoferrin gene, in the common eliminated region 1 on 3 p21.3, following tumour growth in severe combined immunodeficient (SCID) mice. Cancer Lett 191: 155-164, 2003.

40. Kholodnyuk ID, Kozireva S, Kost-Alimova M, Kashuba V, Klein $G$ and Imreh S: Down-regulation of $3 p$ genes, LTF SLC38A3 and DRR1, upon growth of human chromosome 3mouse fibrosarcoma hybrids in severe combined immunodeficiency mice. Int J Cancer 119: 99-107, 2006.

41. Kovacs G, Erlandsson R, Boldog F, Ingvarsson S, MullerBrechlin R, Klein G and Sumegi J: Consistent chromosome 3p deletion and loss of heterozygosity in renal cell carcinoma. Proc Natl Acad Sci USA 85: 1571-1575, 1988.

42. Roiron D, Amouric M, Marvaldi J and Figarella C: Lactoferrinbinding sites at the surface of HT29-D4 cells. Eur J Biochem 186: 367-373, 1989

43. Iacopetta BJ, Morgan EH and Yeoh GCT: Receptor-mediated endocytosis of transferrin by developing erythroid cells from the fetal rat liver. J Histochem Cytochem 31: 336-344, 1983.

44. Damiens E, Mazurier J, El Yazidi I, et al: Effects of human lactoferrin on NK cell cytotoxicity against haematopoietic and epithelial tumour cells. Biochim Biophys Acta 1402: 277-287, 1998.

45. Damiens E, El Yazidi I, Mazurier J, Duthille I, Spik G and Boilly-Marer Y: Lactoferrin inhibits G1 cyclin-dependent kinases during growth arrest of human breast carcinoma cells. J Cell Biochem 74: 486-498, 1999.

46. Norrby K, Mattsby-Baltzer I, Innocenti M and Tuneberg S Orally administered bovine lactoferrin systematically inhibits VEGF(165)-mediated angiogenesis in the rat. Int J Cancer 91: 236-240, 2001.

47. Weinberg ED: Iron withholding: a defense against infection and neoplasia. Physiol Rev 64: 65-102, 1984.

48. Shoji A and Ozawa E: Necessity of transferrin for RNA synthesis in chick myotubes. J Cell Physiol 127: 349-356. 1986.

49. Van Snick JL, Masson PL and Heremans JF: The involvement of lactoferrin in the hyposideremia of acute inflammation. J Exp Med 140: 1068-1084, 1974. 